\title{
Cucumis melo L. Callus Response to Toxins Produced by Myrothecium roridum Tode ex. Fries
}

\author{
Wayne A. Mackay ${ }^{1}$ and Timothy $\mathrm{J} \mathrm{Ng}^{2}$ \\ Department of Horticulture, University of Maryland, College Park, MD 20742 \\ Freddi A. Hammerschlag ${ }^{3}$ \\ U.S. Department of Agriculture, Agricultural Research Service, Plant Molecular Biology Laboratory, \\ Beltsville Agricultural Research Center-West, 10300 Baltimore Avenue, Beltsville, MD 20205-2350
}

Additional index words. melon, mycotoxin, trichothecene, tissue culture

\begin{abstract}
Studies examining exposure methods and callus type were conducted to develop an in vitro selection system using roridin $E$ as a selection agent. Vacuum infiltration of callus with the toxin solution was the only successful selection method at the concentrations tested. Primary callus (callus originating directly from the explant) was not sensitive to roridin $A$ or $\mathbf{E}$ at the concentrations used. Secondary callus (callus produced from primary callus) exhibited a differential response to roridins $A$ and $E$ similar to that of detached-leaf assays. Electrolyte leakage studies of callus were not conclusive in establishing the membrane as the site of toxin action or useful for screening tolerance in vitro. A small percentage of callus from tolerant and susceptible cultivars survived repeated exposure to roridin $\mathbf{E}$ at $50 \mu \mathrm{g} \cdot \mathrm{ml}^{-1}$.
\end{abstract}

The fungus Myrothecium roridum was first reported to be pathogenic to muskmelons (Cucumis melo ) by McLean and Sleeth (1961). Infected melons exhibited lesions on the leaves, stems, and immature and mature fruit (fruit symptoms are typically dark, sunken lesions covered with spores). Myrothecium roridum can cause severe economic losses of melon as a preharvest and postharvest disease. Carter (1980) reported that $M$. roridum caused premature death of the vines and fruit losses in the field and packinghouses in the lower Rio Grande Valley of Texas. Fruit lesions were frequently found at the packinghouses during grading, with losses of up to $30 \%$ in southern Texas (Bruton, 1982).

Myrothecium roridum currently is controlled with fungicides; however, fungicides are not always effective (Carter, 1980). Using resistant cultivars would avoid the problems associated with fungicides. Currently, there is no known source of resistance, although Kuti and $\mathrm{Ng}$ (1987) reported differential responses of fifty melon cultivars to $M$. roridum.

Tissue-culture techniques have produced germplasm with enhanced disease resistance (Daub, 1986; Hammerschlag, 1984). The availability of a defined phytotoxin is advantageous for developing in vitro selection protocols. However, to be useful, toxins must be implicated in the disease development process, act at the cellular level, and have a mode of action that allows recovery of resistance (Daub, 1986; Hammerschlag, 1984).

Bean et al. (1984) reported that trichothecenes produced from the isolate of $M$. roridum were pathogenic to melon in Texas. The macrocyclic trichothecene, roridin $\mathrm{E}$, was isolated in small amounts from liquid cultures of this isolate. Studies by Kuti et al. (1989a-

Received for publication 19 Jan. 1993. Accepted for publication 24 Aug. 1993. Scientific Article no. A6502. Contribution no. 8709 of the Maryland Agricultura Experiment Station (Dept. of Horticulture). Use of a company or product name does not imply approval or recommendation of the product to the exclusion of others, which may also be suitable. These studies were conducted at the USDA-ARS in the Plant Molecular Biology Laboratory, Beltsville, Md. The cost of publishing this paper was defrayed in part by the payment of page charges. Under postal regulations, this paper therefore must be hereby marked advertisement solely to indicate this fact.

${ }^{1}$ Former graduate research assistant. Present address: Texas A \& M Univ. Research and Extension Center, 1380 A \& M Circle, El Paso, TX 79927. To whom reprint requests should be addressed.

${ }^{2}$ Professor.

${ }^{3}$ Plant physiologist. c) suggested that roridin E was a good candidate for in vitro selection studies. Phytotoxin production by the pathogen was implicated in disease development because typical disease symptoms were caused by toxin treatment alone (Kuti et al., 1989b). Kuti et al. (1987, 1989c) reported that roridins A and E increased electrolyte leakage from melon leaf tissue and were useful indicators of cultivar tolerance. Roridin A obtained from an M. roridum strain nonpathogenic to melon did not elicit a cultivar-specific response, while roridin E elicited cultivar responses similar to that of the $M$. roridum isolate pathogenic to melon. Lesions caused by roridin $\mathrm{E}$ were similar to those caused by the pathogenic isolate, and there was a high correlation coefficient between inoculations with the pathogen and roridin $\mathrm{E}$ (Kuti and $\mathrm{Ng}, 1989$ ). Additionally, roridin E significantly increased sporulation of $M$. roridum and lesion diameter on inoculated melon leaves (Kuti et al., 1989b). Cell wall extracts of the susceptible 'Iroquois' significantly increased roridin E production by $M$. roridum in culture, while cell wall extracts from the tolerant 'Hales Best' significantly inhibited roridin E production (Kuti et al., 1989c). Although the mechanism of action of roridin $\mathrm{E}$ in disease development on melon is not clearly established, the above studies suggest that roridin $\mathrm{E}$ is a virulence factor in the disease process.

This research was undertaken to develop in vitro selection protocols using roridin $\mathrm{E}$ and melon cotyledonary callus. The objective of these studies was to determine if roridin $\mathrm{E}$ would be a suitable in vitro selection agent exhibiting host specificity in vitro similar to that in vivo.

\section{Materials and Methods}

Toxin solution preparation. Except for the medium incorporation experiments, toxin solutions were prepared by dissolving roridin $\mathrm{E}$ or $\mathrm{A}$ in $95 \%$ methanol $(\mathrm{MEOH})$, then adding the solution dropwise to continuously stirred double-distilled water $\left(\mathrm{ddH}_{2} \mathrm{O}\right)$. Roridins E and A were obtained from B. Jarvis, Univ. of Maryland (Jarvis et al., 1982). The final MEOH concentration in the stock solution was $5 \%$. Final toxin concentrations were achieved by adding the toxin solution to a one-half strength Murashige and Skoog (MS) salt (Murashige and Skoog, 1962) solution. Toxin solutions were filter-sterilized using $0.2-\mu \mathrm{m}$ filter units.

Plant material and culture conditions. Calli of 'Hales Best', 
'Perlita', and 'Iroquois' muskmelons were used in all the experiments. These cultivars were chosen for their differential host response to $M$. roridum (Kuti and Ng, 1987). 'Hales Best' was the most tolerant, 'Perlita' was intermediate in response, and 'Iroquois' was the most susceptible. Primary callus was collected from cotyledons cultured in the light on IK medium, which consisted of MS inorganic salts, 3\% sucrose, $0.8 \%$ Phytagar (Gibco Laboratories, Grand Island, N.Y.), thiamine- $\mathrm{HCl}$ at $1 \mathrm{mg} \cdot$ liter $^{-1}$, myo-inositol at $100 \mathrm{mg} \cdot$ liter $^{-1}, 8.56 \mu \mathrm{M}$ indole-3-acetic acid (IAA), and $27.9 \mu \mathrm{M}$ kinetin (Moreno et al., 1985). Secondary callus was collected from callus subcultured every 28 days on IK medium. Unless noted otherwise, $\approx 50 \mathrm{mg}$ of callus was cultured on $4 \mathrm{ml}$ of medium contained in each well of the 12-well plates (Costar Corp., Cambridge, Mass.). Cultures were grown for 28 days under 16-h photoperiods $\left(\approx 50 \mu \mathrm{mol} \cdot \mathrm{m}^{-2} \cdot \mathrm{s}^{-1}\right.$ at $\left.25 \pm 2 \mathrm{C}\right)$. Melon callus grown under these conditions was green and friable.

Medium incorporation of roridin E. A concentrated stock solution of roridin $\mathrm{E}$ was prepared by dissolving the toxin in acetone. The stock solution was added to IK medium immediately after autoclaving, for final toxin concentrations of 0.0, 0.5, 1.0, 2.5, 5.0 , and $10 \mu \mathrm{g} \cdot \mathrm{ml}^{-1}$. Primary and secondary cotyledonary calli were divided into approximately equal pieces, weighed, and plated on the medium. In the repeat experiment, the medium was allowed to cool to $\approx 45 \mathrm{C}$ before adding the toxin stock solution.

Vacuum infiltration of callus. Preliminary studies indicated that direct exposure to the toxin resulted in cell death and altered callus growth. To maximize cell death using a minimal amount of scarce toxin material, time course experiments were conducted by vacuum infiltrating the callus for up to $96 \mathrm{~h}$ to determine maximal cell death using $5.0 \mu \mathrm{g} \cdot \mathrm{ml}^{-1}$, the concentration used by Kuti and $\mathrm{Ng}$ (1989). Results of the experiments (data not presented) indicated that a 16-h exposure period yielded maximal cell death, whereas dry and fresh weights of callus incubated in the control solution (no toxin) for $16 \mathrm{~h}$ were not different from those in the control treatment (no incubation in solution).

Primary and secondary calli were placed in $2 \mathrm{ml}$ of either roridin $\mathrm{E}$ or $\mathrm{A}\left(0.0,0.5,1.0,2.5\right.$, or $\left.5.0 \mu \mathrm{g} \cdot \mathrm{ml}^{-1}\right)$ contained in 24 -well plates. The plates were placed in a vacuum desiccator in the hood overnight with a vacuum applied for the duration of the exposure. Calli were then removed and plated on IK medium. Primary callus experiments with roridins $\mathrm{A}$ and $\mathrm{E}$ were conducted several years apart using seed of different age. Seed used to initiate callus in the roridin A experiments were stored for an extended period of time, whereas seed used in the roridin E experiments was $<1$ year old (this seed was produced by hand pollination in the Univ. of Maryland greenhouse).

Electrolyte leakage. Secondary callus was collected from the callus of two 'Perlita' lines designated P42 and P44. P44 callus was friable and light green and had been maintained continuously on IK medium. P42 callus was densely dark green, granular, and much more compact; it originated from the same initial IK experiment as P44 but had been subcultured on basal medium supplemented with [2-isopentyl]adenine (2iP) for 1 month and then continually subcultured on the original IK medium for 2 years. This altered callus morphology was unchanged during the 2 years of culturing on the original IK medium. Callus clumps from both lines were divided into $\approx 50-\mathrm{mg}$ pieces and agitated in sterile distilled water for $2 \mathrm{~h}$ to remove adhering electrolytes. Five calli of each callus line were placed in roridin $\mathrm{E}\left(0.0,0.5,1.0,2.5\right.$, or $\left.5.0 \mu \mathrm{g} \cdot \mathrm{ml}^{-1}\right)$ solutions overnight under a vacuum. After incubation in the toxin solution, the calli were placed in $\mathrm{ddH}_{2} \mathrm{O}$, autoclaved for $1 \mathrm{~h}$, and allowed to cool overnight before conductivity was measured. Electrolyte leakage from the calli (T1) was determined by subtracting the conductivity readings (model CDB-70 conductivity meter; Omega, Stamford, Conn.) of the roridin E treatment solutions before callus incubation from the conductivity of the corresponding roridin $\mathrm{E}$ treatment solutions after callus tissue incubation. Total remaining electrolytes (T2) were determined after disruption. The proportion of electrolyte leakage from the callus tissue was calculated by dividing the electrolyte content of the roridin $E$ treatment solution (T1) by the total electrolyte content $(\mathrm{T} 1+\mathrm{T} 2)$ multiplied by 100 (Kuti et al., 1989b). The experiment was repeated twice.

Callus selection against roridin $E$. Secondary calli of the three cultivars subcultured on IK medium were exposed to the toxin using the vacuum-infiltration method previously described. At the end of each subculture period (28 days), the surviving green and actively growing calli were rechallenged with roridin $\mathrm{E}$. The toxin concentrations for the first serial selection experiment were 5, 10, 20 , and $50 \mu \mathrm{g} \cdot \mathrm{ml}^{-1}$, followed by four transfers with no exposure and then reexposure two times to roridin $\mathrm{E}$ at $50 \mu \mathrm{g} \cdot \mathrm{ml}^{-1}$. In the repeat experiment, there were only two transfers with no exposure before reexposure twice to roridin $\mathrm{E}$ at $50 \mu \mathrm{g} \cdot \mathrm{ml}^{-1}$. For each experiment, 20 callus cultures per cultivar were initially exposed. After each exposure, the percentage of surviving calli (number of calli with at least one actively growing sector divided by the number of calli initially plated) was calculated.

Experimental design and data collection. Except for the selection studies, experiments were designed as split plots, with toxin concentration the whole-plot factor and cultivar the subplot factor. For each treatment combination, there were two 12-well plates with four samples of each cultivar per plate. At the end of each experiment, final dry weights were obtained. Data were analyzed using either analysis of variance or the General Linear Models procedure (SAS Institute, Cary, N.C.). All experiments were repeated at least once. Data from the original experiment and its replication were analyzed separately and together. In all experiments, there were no differences in the results, and data were combined into one data set (16 data points for each treatment) and analyzed first as a split-plot design, then reanalyzed as a completely random design with the nonsignificant error terms combined $(P \leq 0.05)$. In addition, to determine proper least significant difference values for the vacuum-infiltration experiment data, the data were reanalyzed by callus groups to determine the proper mean square error.

\section{Results}

Medium incorporation. Primary callus of 'Iroquois' (susceptible) had the highest final dry weight at all toxin concentrations tested (Fig. 1), whereas 'Hales Best' (tolerant) had the lowest. With secondary callus, there was a smaller difference between the cultivars for final dry weight, a result indicating a difference in the rate of secondary and primary callus growth. There was also a general decline in final dry weights for 'Hales Best' and 'Perlita', except at the highest roridin E concentration, at which the weight of 'Hales Best' was similar to that of the control treatment. 'Iroquois' growth was inhibited little, except at the highest concentration of roridin $\mathrm{E}$, at which dry weight accumulation was reduced significantly compared with the other treatments.

Vacuum infiltration. Primary callus growth rates were apparently influenced by seed age. Roridins $E$ and A vacuum-infiltration experiments were conducted at different times and different seed sources were used. Primary callus for roridin A experiments (Fig. 2) and the first roridin E experiment (Fig. 1) was initiated using seed that was stored for an extended period of time, while all other roridin E experiments used primary callus initiated from seed that 


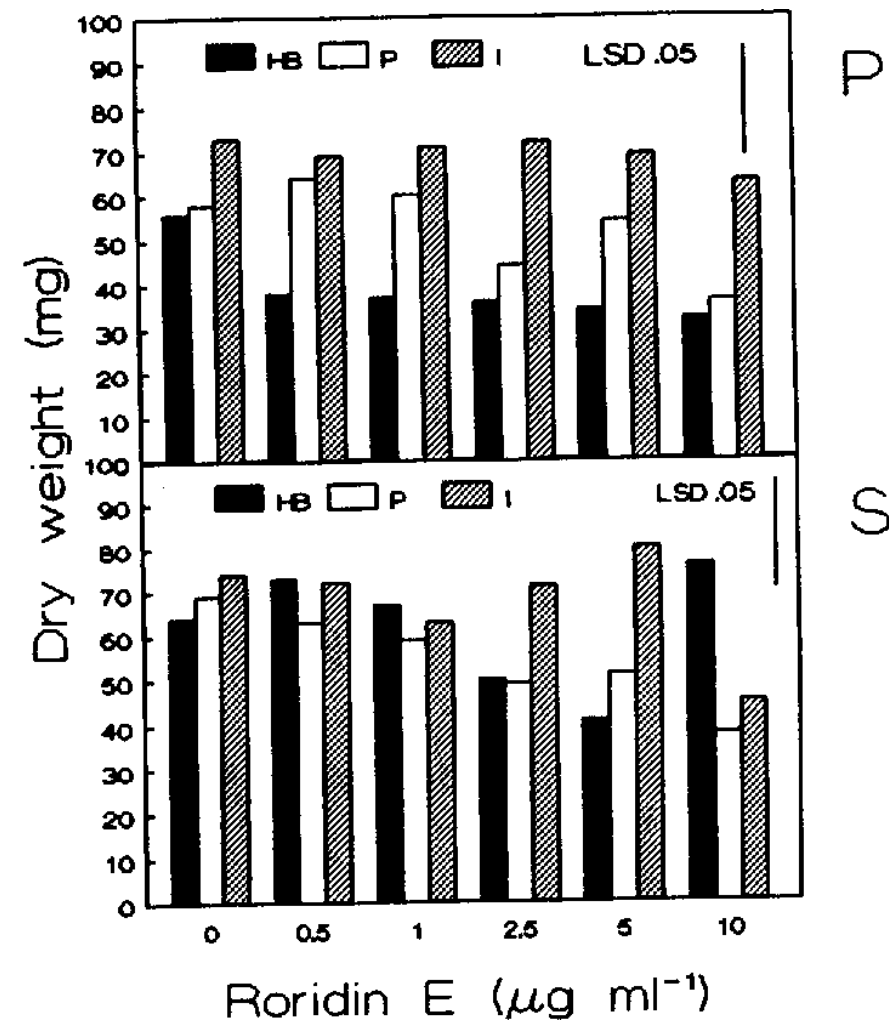

Fig. 1. Effect of roridin E medium incorporation on final dry weights of primary $(\mathrm{P})$ and secondary (S) callus of muskmelons 'Hales Best' (HB), 'Perlita' (P), and 'Iroquois' (I).

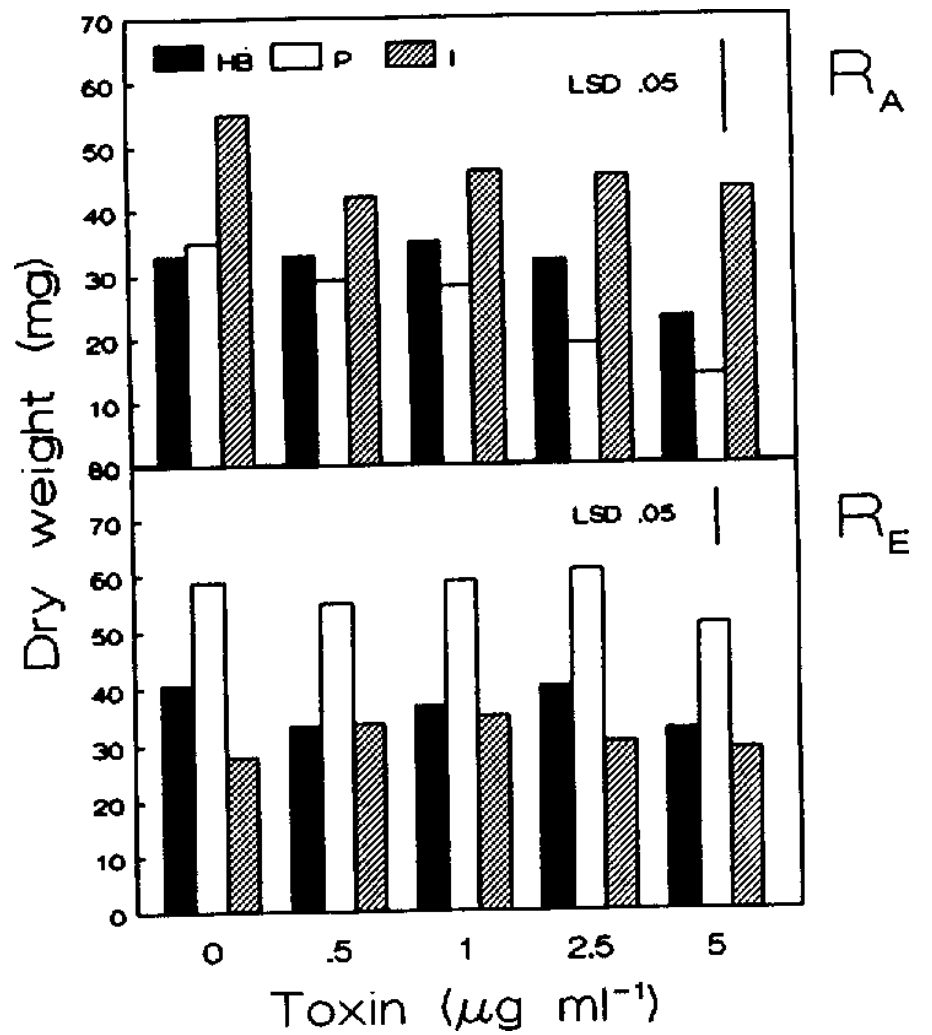

Fig. 2. Effect of roridins $E$ and $A\left(R_{E}\right.$ and $\left.R_{A}\right)$ vacuum infiltration on final dry weight of primary callus of muskmelons 'Hales Best' (HB), 'Perlita' (P), and 'Iroquois' (I). was produced fresh each year (Fig. 2). However, regardless of the relative growth rates of callus in the two groups of experiments, dry weights of primary callus exposed to either roridin A or E and cultured on IK medium were not significantly reduced compared to the control treatment (Fig. 2). Results of the experiments with secondary callus were quite different. Secondary callus exposed to roridins $\mathrm{E}$ and $\mathrm{A}$ exhibited a loss of chlorophyll and necrosis of some of the tissue. Surviving callus tissue was characterized by chlorophyll formation and growth. Final dry weights of callus exposed to roridin A and cultured on IK medium were inversely related to toxin concentration for all three cultivars (Fig. 3). 'Hales Best' and 'Perlita' callus exposed to roridin E and cultured on IK medium had slightly lower dry weight at the higher toxin concentrations compared to the control. 'Iroquois', the susceptible cultivar, was more affected by roridin $\mathrm{E}$, with a significantly reduced final dry weight at the highest toxin concentration.

Electrolyte leakage. There was a highly significant difference in the electrolyte leakage between the two 'Perlita' lines. Electrolyte leakage of P44 (loose, friable, light-green callus) averaged $38 \%$, while P42 (compact, granular, dark-green callus) electrolyte leakage averaged $19.9 \%$ (data not shown). There were no significant differences between the control treatments and the treatments containing roridin $\mathrm{E}$, even at $16 \mathrm{~h}$ of exposure.

Callus selection. 'Hales Best' and 'Iroquois' calli survived the first serial selection experiment with four roridin E-free transfers between toxin exposures (Fig. 4). During the four roridin E-free transfers, 'Hales Best' and 'Iroquois' callus tissue grew and was subdivided into $\approx 50-\mathrm{mg}$ pieces and replated at each transfer. After reexposure to $50 \mu \mathrm{g} \cdot \mathrm{ml}^{-1}$, the surviving sectors grew considerably ( $\approx 75 \%$ of the callus tissue survived in each piece of callus), allowing subdivision of the calli. By the end of the experiment, there were about the same number of 'Iroquois' and 'Hales Best'

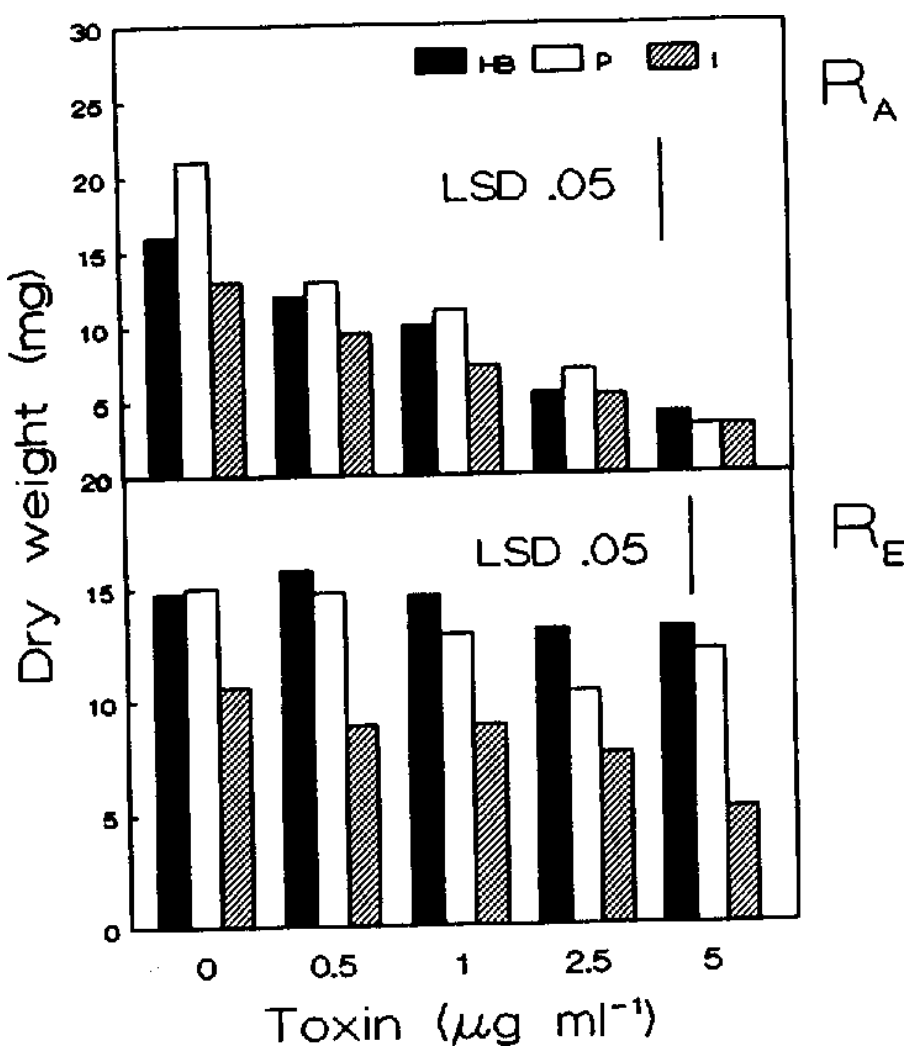

Fig. 3. Effect of roridins $E$ and $A\left(R_{E}\right.$ and $\left.R_{A}\right)$ vacuum infiltration on final dry weight of secondary callus of muskmelons 'Hales Best' (HB), 'Perlita' (P), and 'Iroquois' (I).

J. AMER. Soc. Hort. ScI. 119(2):356-360. 1994 


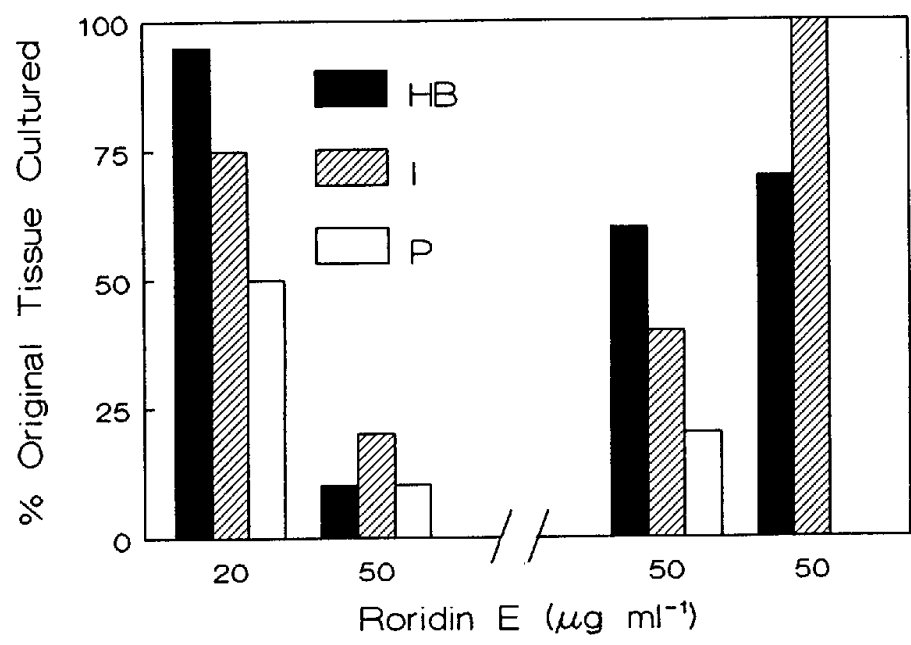

Fig. 4. Percentage of calli (number of calli with surviving sectors divided by the number of originally plated) after each exposure to roridin E. Break in X axis indicates period of subculture without exposure to roridin E. 'Hales Best' (HB), 'Perlita' (P), and 'Iroquois' (I).

callus cultures as at the beginning of the experiment. When the callus tissues were reexposed, all of the 'Iroquois' callus cultures had surviving tissue and slightly more than half of the 'Hales Best' callus cultures had surviving sectors. However, 'Perlita' callus tissue did not respond similarly, and all tissue was killed by the end of the experiment. In the second experiment, before subculture on roridin E-free medium, results were similar to those of the first experiment. However, only 'Iroquois' callus survived the reexposure to roridin $\mathrm{E}$ at $50 \mu \mathrm{g} \cdot \mathrm{ml}^{-1}$, with only a small amount of tissue surviving at the end of the experiment (data not shown).

\section{Discussion}

The only effective method of exposing melon callus tissue to either roridin $\mathrm{A}$ or $\mathrm{E}$ at the concentrations tested was by immersing the callus in the toxin solution and placing the solution under a vacuum. Primary and secondary callus responded differently to exposure to both roridins. Primary callus seemed insensitive to the toxins, while secondary callus exposure resulted in significant cell death and lower callus growth rates of all cultivars to roridin A and significant cell death and lower callus growth rates for 'Iroquois' in response to roridin E. Secondary callus also lost chlorophyll when challenged by both toxins, similar to the response of leaf tissue when exposed to roridins A and E. These results mimicked those of detached-leaf inoculations with the toxins (Kuti and $\mathrm{Ng}$, 1987).

Studies using leaf disc assays suggested that one site of toxin action was the cell membrane (Kuti et al., 1989) and that tolerance to $M$. roridum could be assayed using electrolyte leakage studies. However, electrolyte leakage does not seem useful as an indicator of tolerance to roridin E in vitro. Experiments with two lines of 'Perlita' secondary callus with marked differences in morphology exhibited significant differences in electrolyte leakage, a result indicating that callus morphology was more important than genotypic differences. Additionally, results of electrolyte leakage studies using callus tissue of the three cultivars were inconclusive and were not useful as assays of tolerance in vitro (data not shown).

In both selection experiments, it was possible to select for cells insensitive to roridin E. After subculture on roridin E-free medium in Expt. 1, there was a considerable amount of 'Iroquois' and 'Hales Best' callus tissue surviving during the repeated exposures to high levels of roridin $\mathrm{E}$, a result suggesting that selection may be possible with two out of the three cultivars. Lack of survival of 'Perlita' callus suggests that insufficient tissue-culture-induced variation occurred during callus subculture. Differences between these cultivars in the amount of somaclonal variation were also observed under field conditions, with unselected 'Iroquois' regenerants having the greatest amount of variation and 'Perlita' having the least amount of variation (data unpublished). The above suggests that 'Perlita' was not amenable for selection and provides additional evidence for the effect of genotype on the generation of somaclonal variants, as documented in other species (Hammerschlag, 1990; Lorz, 1984; McCoy et al., 1982).

It was unclear whether survival of toxin-challenged callus tissue, after a period of subculture in the absence of roridin E, was the result of escapes or from cells insensitive to the toxin. In a study with peach (Hammerschlag, 1988), escapes and leaf-spot-resistant plants were produced after three subcultures on media with toxin, one subculture in the absence of toxin, and then rechallenging only once on media with toxin. 'Hales Best' and 'Iroquois' callus survived rechallenge with two exposures of roridin $E$ that followed four subcultures in the absence of toxin, a result suggesting the presence of toxin insensitive cells. Only subsequent studies that include testing regenerants of the surviving calli for response to $M$. roridum will determine conclusively if toxin selection has been successful.

In conclusion, roridin $\mathrm{E}$ seems to be a good candidate for further in vitro selection studies if callus types are selected carefully and sufficient genotypes are used to generate callus. Host response mimicked that of whole plants only when friable secondary callus was used. Callus tissue lost chlorophyll rapidly and cell necrosis was similar to that of leaf tissue when exposed to the toxin, a result indicating that in vitro cellular activity of the toxin was similar to in vivo activity. The effect of toxin exposure on the morphogenic capacity of callus is unknown and needs to be elucidated.

\section{Literature Cited}

Bean, G.A., T. Fernando, B.B. Jarvis, and B. Bruton. 1984. The isolation and identification of trichothecene metabolites from a plant pathogenic strain of Myrothecium roridum J. Natl. Prod. 47:727-729.

Bruton, B.D. 1982. Myrothecium roridum, a probable devastating pathogen of muskmelon in south Texas. Phytopathology 72:355. (Abstr.)

Carter, W. 1980. Incidence and control of Myrothecium roridum on cantaloupe in relation to time of fungicide application. Plant Dis. 64:872-874.

Daub, M.E. 1986. Tissue culture and the selection of resistance to pathogens. Annu. Rev. Phytopathol. 24:159-186.

Hammerschlag, F.A. 1984. In vitro approaches to disease resistance, p. 453-490. In: G.B. Collins and J.G. Petolino (eds.). Applications of genetic engineering to crop improvement. Matinus Nijhoff/Dr. W. Junk Publishers, Dordrecht.

Hammerschlag, F.A. 1988. Selection of peach cells for insensitivity to culture filtrates of Xanthomonas campestris pv. pruni and regeneration of resistant plants. Theoretical Applied Genet. 76:865-869.

Hammerschlag, F.A. 1990. Resistance responses of plants regenerated from peach callus cultures to Xanthomonas campestris pv. pruni. J. Amer. Soc. Hort. Sci. 115:1034-1037.

Jarvis, B.B., G.P. Stahly, G. Pavanasasivam, J.O. Midiwo, T.A. DeSilva, C.E. Holmlund, E.P. Mazzola, and R. Geoghegan, Jr. Isolation and characterization of the trichoverroids and new roridins and "verrucarins." J. Organic Chem. 117:1124.

Kuti, J.O., G.A. Bean, W.A. Mackay, and T.J Ng. 1989a. Influence of muskmelon cell wall polysaccharides on roridin $\mathrm{E}$ production by a pathogenic strain of Myrothecium roridum. Mycopathologia 108:139_ 144.

Kuti, J.O. and T.J Ng. 1987. Reactions of muskmelon cultigens to 
Myrothecium roridum. HortScience 22:635-637.

Kuti, J.O. and T.J Ng. 1989. Combining ability estimates for muskmelon tolerance to Myrothecium roridum and its toxic metabolite, roridin E. J. Amer. Soc. Hort. Sci. 114:319-321.

Kuti, J.O., T.J Ng, and G.A. Bean. 1987. Phytotoxic effects of trichothecene metabolites from pathogenic strains of Myrothecium roridum on $\mathrm{Cucu}$ mis melo L. Biodeterioration Res. 1. Plenum Publishing Corp., New York. p. 213-222.

Kuti, J.O., T.J Ng, and G.A. Bean. 1989b. Possible involvement of pathogen-produced trichothecene metabolite in Myrothecium leaf spot of muskmelon. Physiol. Mol. Plant Pathol. 34:41-54.

Kuti, J.O., T.J Ng, K.C. Gross, and H.E. Moline. 1989c. Cell wall monosaccharide composition and muskmelon resistance to Myrothecium roridum. J. Phytopathol. 126:293-304.

Lorz, H. 1984. Variability in tissue cultured derived plants, p. 103-114. In: W. Arber (ed.). Genetic manipulation; impact on man and society. Cambridge Univ. Press, Cambridge.

McCoy, T.J., R.L. Phillips, and H.W. Rines. 1982. Cytogenetic analysis of plants regenerated from oat (Avena sativa) tissue cultures; high frequency of partial chromosome loss. Can. J. Genet. Cytol. 24:37-50. McLean, D.M. and B. Sleeth. 1961. Myrothecium rind rot of cantaloupe. Plant Dis. Rpt. 45:728-729.

Moreno, V., M. Garcia-Sogo, I. Granell, B. Garcia-Sogo, and L.A. Roig. 1985. Plant regeneration from calli of melon (Cucumis melo L., cv. 'Amarillo Oro'). Plant Cell Tissue Organ Cult. 5:139-146.

Murashige, T. and F. Skoog. 1962. A revised medium for rapid growth and bioassays with tobacco cultures. Physiol. Plant 15:473-497. 